\title{
The ecological condition of vermetid platforms affects the cover of the alien seaweed Caulerpa cylindracea
}

\author{
Marc Terradas-Fernández ${ }^{1}$, Miguel Valverde-Urrea ${ }^{1}$, Nuria Casado-Coy ${ }^{1}$, Carlos Sanz-Lazaro ${ }^{2,3}$ \\ ${ }^{1}$ Departamento de Ciencias del Mar y Biología Aplicada, Facultad de Ciencias, Universidad de Alicante, \\ Aptdo. Correos 99, 03080 Alicante, Spain. \\ (MT-F) (Corresponding author) E-mail: marcbentos@gmail.com. ORCID iD: https://orcid.org/0000-0002-1916-5337 \\ (MV-U) E-mail: miguel_27692@ hotmail.com. ORCID iD: https://orcid.org/0000-0002-5708-5258 \\ (NC-C) E-mail: ncasadocoy@ua.es. ORCID iD: https://orcid.org/0000-0003-4348-2225 \\ ${ }^{2}$ Departamento de Ecología, Universidad de Alicante, P.O. Box 99, E-03080 Alicante, Spain \\ ${ }^{3}$ Multidisciplinary Institute for Environmental Studies (MIES), Universidad de Alicante, P.O. Box 99, \\ E-03080 Alicante, Spain. \\ (CS-L) E-mail: carsanz@ua.es. ORCID iD: https://orcid.org/0000-0002-4431-1762
}

\begin{abstract}
Summary: The seaweed Caulerpa cylindracea Sonder is one of the most important invaders on Mediterranean rocky shores. However, many driving pressures affecting its spread are poorly understood and seem to involve the interactions between abiotic and biotic factors. We studied the invasiveness of $C$. cylindracea on two shallow vermetid platforms with a contrasting ecological status on which $C$. cylindracea was first detected simultaneously 15 years ago. The cover values of $C$. cylindracea and the other macroalgal species were assessed for one year, embracing the whole platform width. Caulerpa cylindracea cover was higher on the platform that had a low ecological status, especially during warmer months at the outer seaward margin. The ecological status of the overstory of native species seems to be a key point conditioning the success of C. cylindracea invasiveness on these platforms.
\end{abstract}

Keywords: rocky shores; phytobenthos; community composition; Caulerpa cylindracea; vermetid platforms; man-induced effects; Mediterranean.

El estado ecológico de las plataformas de vermétidos afecta la cobertura de la especie exótica Caulerpa cylindracea

Resumen: El alga Caulerpa cylindracea Sonder es una de las principales especies invasoras de las costas rocosas mediterráneas. Sin embargo, muchos condicionantes que afectan su proliferación son poco conocidos y parecen ser el resultado de la interacción entre factores bióticos y abióticos. Estudiamos la invasividad de $C$. cylindracea en dos plataformas de vermétidos que presentan un estado ecológico contrastado y en las que se detectó simultáneamente $C$. cylindracea hace 15 años. Los valores de cobertura de $C$. cylindracea y del resto de macroalgas fueron evaluados durante un año abarcando toda la anchura de la plataforma. La cobertura de C. cylindracea fue mayor en la plataforma que presentaba un pobre estado ecológico, especialmente durante los meses cálidos y en el margen externo y más expuesto de la plataforma. El estado ecológico del dosel, formado por las especies nativas, parece un condicionante clave en el éxito de la invasividad de $C$. cylindracea en estas plataformas de vermétidos.

Palabras clave: costas rocosas; fitobentos; composición de la comunidad; Caulerpa cylindracea; plataformas de vermétidos; efectos antropogénicos; Mediterráneo.

Citation/Como citar este artículo: Terradas-Fernández M., Valverde-Urrea M., Casado-Coy N., Sanz-Lazaro C. 2020. The ecological condition of vermetid platforms affects the cover of the alien seaweed Caulerpa cylindracea. Sci. Mar. 84(2): 181-191. https://doi.org/10.3989/scimar.04984.06A

Editor: E. Cebrián.

Received: July 31, 2019. Accepted: March 30, 2020. Published: April 14, 2020.

Copyright: ( $) 2020$ CSIC. This is an open-access article distributed under the terms of the Creative Commons Attribution 4.0 International (CC BY 4.0) License.

\section{INTRODUCTION}

The Mediterranean Sea hosts over 80 introduced macrophyte species (Boudouresque and Verlaque
2002), so it is considered a hotspot for marine alien species (Rilov and Galil 2009). At least one-ninth of them are invasive, affecting food provision for human consumption, natural cycling of nutrients, diversity and 
complexity of assemblages and cultural services such as recreational uses (Katsanevakis et al. 2014). The introduced species Caulerpa cylindracea Sonder has shown notorious effects (Montefalcone et al. 2015). Its vegetative propagation by fragmented thalli allows it to attach itself to anchors and disperse by drifting. Marinas and harbours are the putative focus from which it starts to expand locally (Verlaque et al. 2003, Cantasano et al. 2017), as has been observed for its conspecific invader Caulerpa taxifolia (Vahl) Agardh (Boudouresque et al. 1995). Moreover, the invasiveness from harbours and marinas to the neighbouring urban shores could be facilitated by the usually higher values of some human-induced stressors such as eutrophication and sedimentation, which also affect the native recipient assemblages (Connell et al. 2008), generating synergistic effects between the invader and the stressors mentioned above (Bulleri et al. 2010, Gennaro and Piazzi 2011, Airoldi et al. 2015). The invasion of $C$. cylindracea has serious effects on recipient communities, but assemblages with large canopy-forming species seem to dampen the effects of the invasion (Ceccherelli et al. 2002). Thus, the impact on recipient communities could be related to their state of health, degraded ones being more prone to invasion because of the increased supply of limiting resources such as nutrients (due to eutrophication), or light and space when recipient canopy-forming species decrease in cover, allowing the spread of the exotic ones (Huenneke et al. 1990, Marín-Guirao et al. 2015). Many studies have detected that unhealthy native communities usually show higher cover values of $C$. cylindracea than healthy ones with a good status of canopy-formers, either involving seaweeds and seagrasses (Ruitton et al. 2005, Ceccherelli et al. 2014, Bulleri et al. 2017) or gorgonians (Ponti et al. 2018). Furthermore, the homogenization effect on community composition and structure caused by the invasion could involve other processes such as impaired fish recruitment (Cheminée et al. 2016).

In the eastern Iberian Peninsula, $C$. cylindracea recently spreads over the coastal area between Catalonia (García et al. 2015) and Andalusia (Altamirano et al. 2014), where it shows a similar distribution pattern to that reported in other Mediterranean regions (Verlaque et al. 2003, Klein and Verlaque 2008). Thus, it thrives in shallow subtidal waters and in deep subtidal habitats beyond $30 \mathrm{~m}$ depth. It is more abundant on margins of Posidonia meadows or on dead Posidonia matte but also colonizes maerl bottoms and photophilous assemblages (Ruiz et al. 2011, Enguix et al. 2014, García et al. 2015).

The detection of $C$. cylindracea in vermetid platforms of the southeastern Iberian Peninsula (PenaMartín et al. 2003) and its high cover values in some locations could shed light on the drivers fostering or hampering its invasiveness.

Vermetid platforms constitute a distinctive Mediterranean habitat, yet it has been highly neglected to the present day (Milazzo et al. 2016). These shallow systems are present in southeastern Iberian littoral shores (Templado et al. 2016) and other warm Mediterranean areas and subtropical seas (Laborel and Kempf 1965, Safriel 1975). Vermetid platforms are well developed in limestone rocks, and their assemblages show a distinctive zonal pattern. Thus, in non-degraded situations, an outer vermetid rim is followed by fucoid algae forming a continuous belt on relatively exposed shores. In less exposed situations, such as in the inner parts of such platforms, low stands of smaller algae flourish and include dictyotacean algae as an important group. Encrusting corallines with vermetids also dominate the innermost part. Vermetid platforms harbour many Mediterranean endemisms and contribute to the increase in regional diversity as a result of the environmental gradient generated over the platform (Milazzo et al. 2016). The shallowness of these platforms entails that these systems are subjected to many anthropogenic stressors (Ballesteros et al. 2007). Thus, the vermetid platforms in the eastern Mediterranean have been severely impaired in a few decades (Galil 2013, Badreddine et al. 2019). Putative reported drivers of this impoverishment are the rise in sea level, global warming, trampling, acidification and all factors linked to human activities, including water deterioration (Milazzo et al. 2004, 2014, Badreddine et al. 2019). As for bioinvasions, little direct information has been reported despite their likely effects on these platforms. The invasive red sea mussel Brachydontes pharaonis (Fisher, 1870) is colonizing the vermetid platforms in the eastern Mediterranean, spreading towards the west (Milazzo et al. 2016). This invasive species was considered an inferior competitor to the native ones, but by increasing the pool of recruits, it became dominant at the expense of other indigenous sessile species (Rilov et al. 2004, Didham et al. 2007). Little is known about the effects of $C$. cylindracea on these shallow systems. In vermetid platforms with undegraded macroalgal communities, $C$. cylindracea has been mainly reported in a patchy distribution within the vermetid platform, in most cases with low cover values. The alga grew intermingled with the thalli of other macroalgae without any clear relationship between the abundance values of $C$. cylindracea and those of the dominant macroalgae (Ramos-Esplà et al. 2008, Balistreri and Mannino, 2017). However, in the south of Alicante Bay, we detected high cover values of $C$. cylindracea on degraded vermetid platforms distinguished by their degraded macroalgal composition, which is attributable to the eutrophication of Alicante Bay (Aranda et al. 1994, Aguilar 2009). The C. cylindracea population of degraded vermetid platforms contrasts with the low cover values observed in the nearby location of Cabo de las Huertas, though both locations happen to be the first ones where this invasive species was detected in Alicante province 15 years ago (Pena-Martín et al. 2003, Terradas-Fernández et al. 2018).

In order to understand whether the ecological status of vermetid platforms could be involved in the abundance of $C$. cylindracea, an annual survey was carried out in both locations, comparing the abundance of the macroalgal species forming overstory with the abundance of $C$. cylindracea. Environmental variables informative of anthropogenic affectation (sediment cover and nutrient concentration) were also measured. Hypotheses that could explain any differences regarding the cover of $C$. cylindracea and the ecological 


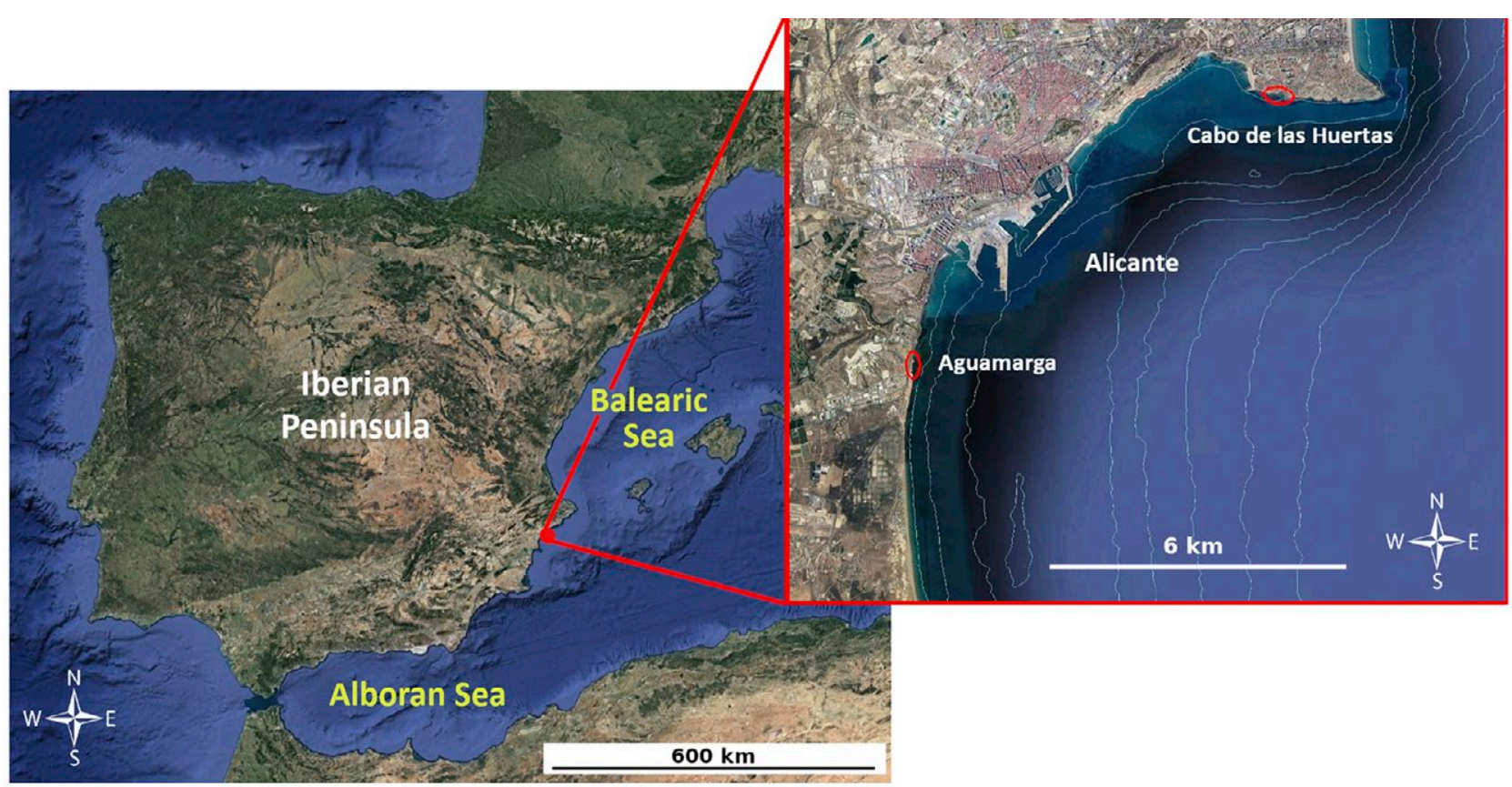

Fig. 1. - Study area showing the sampling locations: Cabo de las Huertas (the non-degraded location) and Aguamarga (the anthropogenic-degraded location). Isobath interval is equal to five metres. Modified from Google Earth.

status of the recipient macroalgal communities were discussed.

\section{MATERIALS AND METHODS}

\section{Study site}

The study took place in two ecologically contrasting locations with shallow vermetid platforms in Alicante, Spain, soutwestern Mediterranean (Fig. 1). One location was Cabo de las Huertas, on the north side of Alicante Bay $\left(38^{\circ} 21^{\prime} 10^{\prime \prime} \mathrm{N}, 0^{\circ} 25^{\prime \prime} \mathrm{W}\right)$, with no signs of severe alteration due to anthropogenic stressors (Terradas-Fernández et al. 2018), and the other was Aguamarga, located in the south of Alicante $\left(38^{\circ} 18^{\prime} 06^{\prime \prime} \mathrm{N}\right.$, $0^{\circ} 31^{\prime} 05^{\prime \prime} \mathrm{W}$ ).

Aguamarga is close to the port of Alicante and near the sewage outfalls of a waste treatment plant. The vermetid reefs are completely degraded, but some dead vestiges have been reported (Aranda et al. 1994 and references therein). According to Aranda et al. (1994), the main putative cause of this degradation is the high nutrient concentration attributed to eutrophication. Both locations are currently monitored to evaluate the ecological status at a regional scale to implement the European Water Framework Directive (WFD, 2000/06/ FC). Several reports confirm the persistent contrasting ecological status of the two locations, Aguamarga being a "bad status spot" surrounded by rocky shores showing a better ecological status (Ramos-Esplà et al. 2011). Thus, we will consider Cabo de las Huertas henceforward as the non-degraded location and Aguamarga as the degraded one.

The invasive species $C$. cylindracea has occupied the shallow platforms of both locations for at least 15 years since it was first detected in the province of Alicante (Pena-Martín et al. 2003, Ramos-Esplà, pers. comm.).

\section{Sampling and data collection}

Three 10-m-long sites parallel to the shore and $20 \mathrm{~m}$ apart were chosen at each location. An exhaustive check was previously conducted throughout the platform system in order to find representative sites with similar platform widths between locations. Three zones parallel to the shore were established at each assigned site along the platform: a) the inner zone (ca. 2 $m$ width), which was located in the innermost part of these platforms; b) the mid-platform zone, which occupied most of the platform (ca. $5 \mathrm{~m}$ width); c) and the exposed outer margin zone (the outer platform zone) in the seaward direction (ca. $1 \mathrm{~m}$ width) (Fig. 2).

The sampling was carried out on a flat, homogeneous platform, avoiding crevices, cuvettes or sloped surfaces. The study lasted for one year, and surveys were carried out approximately every month. In every survey, three random replicates were sampled in every zone at each site. Each sampled replicate had a surface area of $625 \mathrm{~cm}^{2}$, wherein the cover of each taxon was calculated using a quadrat subdivided into 25 subquadrats, giving a score from zero to four on each one (Dethier et al. 1993). All zones were surveyed at their midpoint at each site. The platforms had similar widths at both locations (ca. $8 \mathrm{~m}$ ). Sediment cover was measured using the same criteria as those applied to taxa cover (Terradas-Fernández et al. 2018).

Water-dissolved nutrients (phosphates, nitrates, nitrites and ammonia) were analysed just beyond the outer zone ( $0.3 \mathrm{~m}$ depth) at intervals of 1-2 months using two $50 \mathrm{~mL}$ plastic falcons per location to sample $(n=2)$. The seawater was filtered using a Maroon PVDF Syringe Filter with a pore size of $0.45 \mu \mathrm{m}$ and frozen. The analysis was carried out using an Automated Wet Chemistry Analyser (Skalar Analytical B.V., Breda, the Netherlands). 

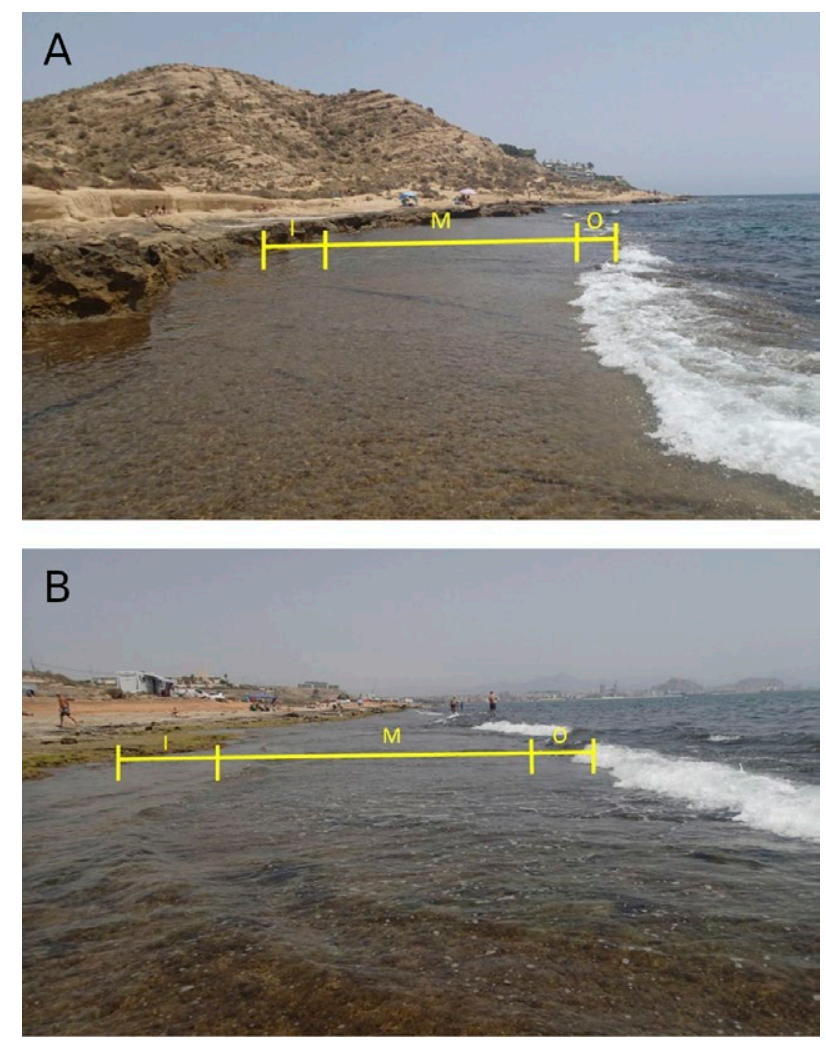

Fig. 2. - Zones surveyed at the non-degraded location (A) and the degraded location (B). Inner zone (I), mid-platform zone (M), outer platform zone $(\mathrm{O})$

\section{Data analysis}

In order to test whether assemblages were significantly different throughout a year, a similarity matrix was generated on the basis of taxa cover values using the Bray-Curtis distance. The cover values were square-root transformed to lower the effects of the dominant taxa. A permutational multivariate analysis of variance (PERMANOVA) was performed to analyse the multivariate assemblage data using a fourway analysis to test the effects of location (a fixed factor with two levels: degraded and non-degraded), zone (a fixed factor with three levels: outer platform zone, mid-platform zone and inner platform zone) and date (a fixed factor with 12 levels: 12 surveys). Site (3 levels) was a random factor nested in location. A principal coordinate ordination (PCO) was performed to organize samples according to their assemblage composition, pooling replicates and sites by calculating distance between centroids. Another PCO without pooling was performed to visualize the vector overlay of taxa with a correlation higher than 0.3 with the PCO axes.

The cover of $C$. cylindracea, sediment and overstory-forming taxa (that is, those taxa able to generate dense and conspicuous stands forming large patches or horizons) were assessed using a univariate PERMANOVA analysis through the same multivariate analysis design. Nutrient concentrations were assessed by two-way univariate PERMANOVA, considering location and date as fixed factors. Phosphates and total nitrogen concentration (ammonia, nitrites and nitrates) were analysed separately.

Post-hoc tests were performed using pairwise comparisons when significant interactions were found. Univariate analyses were carried out from a Euclidean distance matrix instead of the Bray-Curtis one used in the multivariate case (Anderson et al. 2008). Analyses were performed using the PRIMER-E® v.7 + PERMANOVA package (Clarke and Gorley 2015, Anderson et al. 2008).

\section{RESULTS}

\section{Environmental variables}

Nutrient concentration showed high temporal variability (Fig. 3, Supplementary material Table S1). However, an interaction effect between location and date was detected. The degraded location usually showed a higher phosphate concentration, although a peak in phosphates was detected in the non-degraded one in August 2017. As for the total nitrogen concentration (total amount of ammonia, nitrates and nitrites), the pattern was analogous, but pairwise tests showed no significant differences between locations and dates.

There was also an interaction effect between location, zone and date regarding sediment cover (Fig. 3, Table S2). When significant, these differences were usually due to higher cover values in the degraded location. In both locations, the sediment cover showed a decreasing pattern from the inner zone to the outer one.

\section{Assemblages}

With regard to species composition, there was a significant interaction effect between location, zone and date (Table 1A). Furthermore, pairwise tests show that the effect was maintained throughout the year among all levels of these fixed factors (Table 1B). The PCO shows that location was the main factor affecting the arrangement of the samples during the entire annual cycle (Fig. 4A). The most distinctive species of the degraded location were Ellisolandia elongata (Ellis and Solander) Hind and Saunders, Ulva laetevirens Areschoug and Derbesia tenuissima (Moris and De Notaris) Crouan and Crouan, whereas the "Laurencia complex" (mainly Palissada tenerrima (Cremades) Serio, Cormaci, Furnari and Boisset), Jania spp., Padina pavonica (Linnaeus) Thivy and Dictyota spp. (mainly Dictyota spiralis Montagne and Dictyota fasciola (Roth) Lamouroux) were the most distinctive ones of the non-degraded location. Turf species (germlings and small caespitose algae) were more abundant at the degraded location and on the inner margin of the non-degraded one. At the degraded location, most taxa included in this category were small green filamentous algae, Ceramium complex, Herposiphonia tenella (Agardh) and Erythrotrichiaceae, whereas at the non-degraded location that group was dominated by an eclectic component of Ceramiaceae and Rhodomelaceae $(\mathrm{Ce}$ ramium spp., Spyridia filamentosa (Wulfen) Harvey; Herposiphonia secunda (C. Agardh) Ambronn; Lo- 

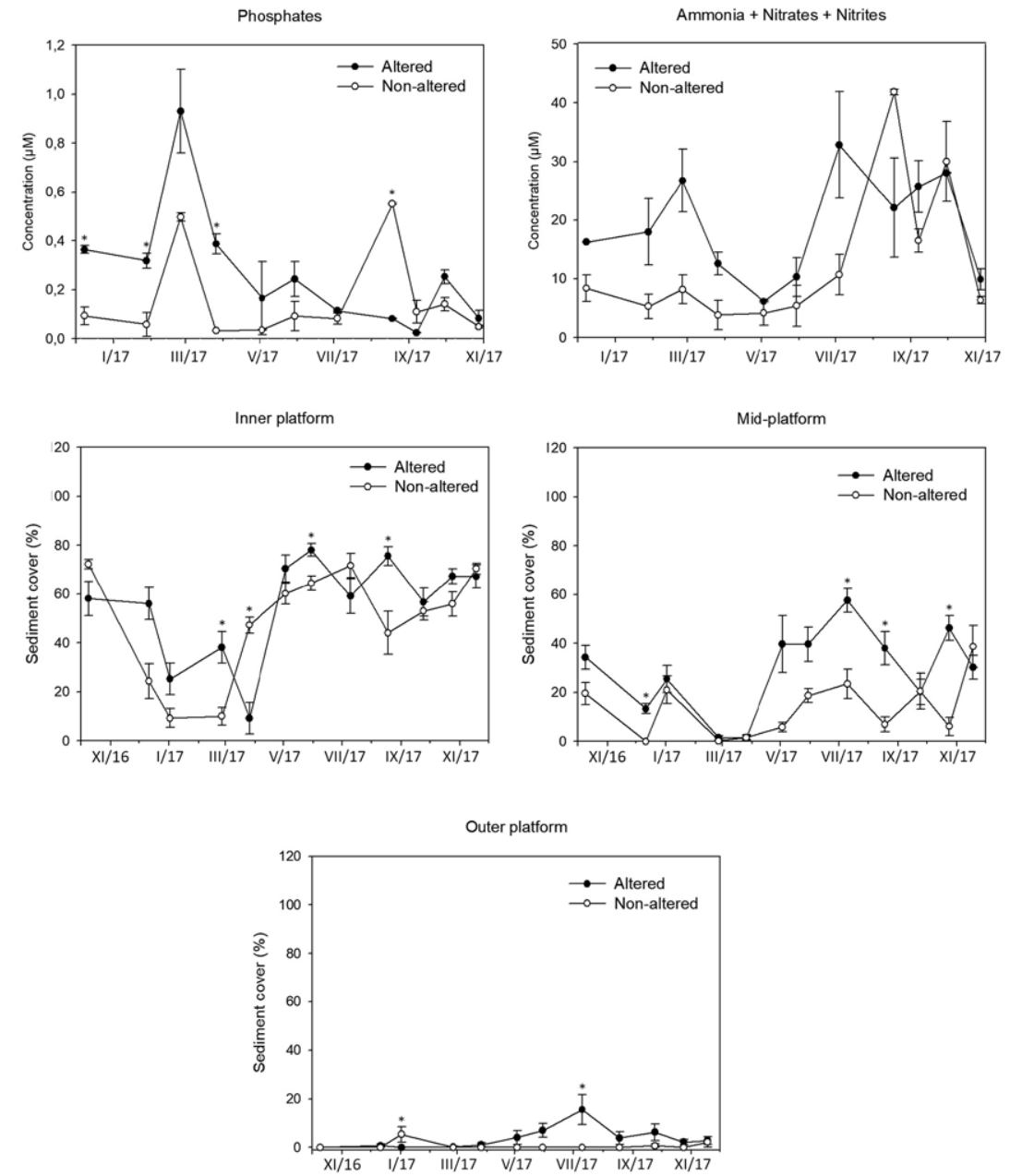

Fig. 3. - Values of nutrient concentration and sediment cover for each location (degraded and non-degraded). Vertical bars: standard error. Asterisks indicate significant differences between locations $(\alpha=0.05)$.

Table 1. - A, summary of a four-factor PERMANOVA test (with location, zone, date and site nested in location) comparing all taxa cover values from all the samples. Lo, location; Zo, zone; $\mathrm{Da}$, date; $\mathrm{Si}$, site; $\left(^{*}\right)$ Monte Carlo p-value $=0.001$. B, pairwise tests for the term 'LoxZoxDa' for pairs of levels of factor 'Location' (Monte Carlo p-values).

\begin{tabular}{|c|c|c|c|c|c|c|}
\hline $\begin{array}{l}\text { A, four-factor PERMANOVA test } \\
\text { Source of variation }\end{array}$ & $\mathrm{df}$ & SS & MS & Pseudo-F & $\mathrm{p}($ perm $)$ & Permutations \\
\hline Lo & 1 & $6,04 \mathrm{E}+09$ & $6,04 \mathrm{E}+09$ & 252.46 & 0.093 & $10 *$ \\
\hline Zo & 2 & $1,33 \mathrm{E}+09$ & $6,66 \mathrm{E}+04$ & 39.863 & 0.001 & 999 \\
\hline $\mathrm{Da}$ & 11 & $2.48 \mathrm{E}+05$ & $2,25 \mathrm{E}+04$ & 13.457 & 0.001 & 997 \\
\hline $\mathrm{Si}(\mathrm{Lo})$ & 4 & 9574.1 & 2393.5 & 38.653 & 0.001 & 998 \\
\hline LoxZo & 2 & $1,20 \mathrm{E}+09$ & $5,99 \mathrm{E}+04$ & 35.88 & 0.001 & 999 \\
\hline LoxDa & 11 & $1,95 \mathrm{E}+09$ & $1,77 \mathrm{E}+04$ & 10.583 & 0.001 & 999 \\
\hline $\mathrm{Zo} \times \mathrm{Da} \times \mathrm{Si}(\mathrm{Lo})$ & 22 & $1,59 \mathrm{E}+09$ & 7220.00 & 5.654 & 0.001 & 998 \\
\hline $\mathrm{Zo} \times \mathrm{Si}(\mathrm{Lo})$ & 8 & 13363.00 & 1670.4 & 26.975 & 0.001 & 999 \\
\hline $\mathrm{Da} \times \mathrm{Si}(\mathrm{Lo})$ & 44 & 73715.00 & 1675.3 & 27.055 & 0.001 & 998 \\
\hline LoxZoxDa & 22 & $1,23 \mathrm{E}+09$ & 5570.4 & 43.622 & 0.001 & 998 \\
\hline $\mathrm{Zo} \times \mathrm{Da} \times \mathrm{Si}(\mathrm{Lo})$ & 88 & $1,12 \mathrm{E}+09$ & 1277.00 & 20.622 & 0.001 & 997 \\
\hline Residual & 432 & $2,68 \mathrm{E}+09$ & 619.23 & & & \\
\hline
\end{tabular}

B, PAIRWISE TESTS for the term 'LoxZoxDa' for pairs of levels of the factor 'Location'

\begin{tabular}{lccc} 
Date & Inner zone & Mid-zone & Outer zone \\
\hline $09 / 10 / 2016$ & 0.001 & 0.004 & 0.003 \\
$08 / 12 / 2016$ & 0.001 & 0.001 & 0.001 \\
$02 / 01 / 2017$ & 0.006 & 0.001 & 0.001 \\
$25 / 02 / 2017$ & 0.002 & 0.001 & 0.001 \\
$26 / 03 / 2017$ & 0.003 & 0.001 & 0.001 \\
$03 / 05 / 2017$ & 0.01 & 0.001 & 0.001 \\
$30 / 05 / 2017$ & 0.001 & 0.001 & 0.001 \\
$04 / 07 / 2017$ & 0.004 & 0.001 & 0.001 \\
$18 / 08 / 2017$ & 0.006 & 0.002 & 0.001 \\
$30 / 09 / 2017$ & 0.006 & 0.001 & 0.001 \\
$28 / 10 / 2017$ & 0.003 & 0.001 & 0.001 \\
$18 / 11 / 2017$ & 0.001 & & 0.001 \\
\hline
\end{tabular}



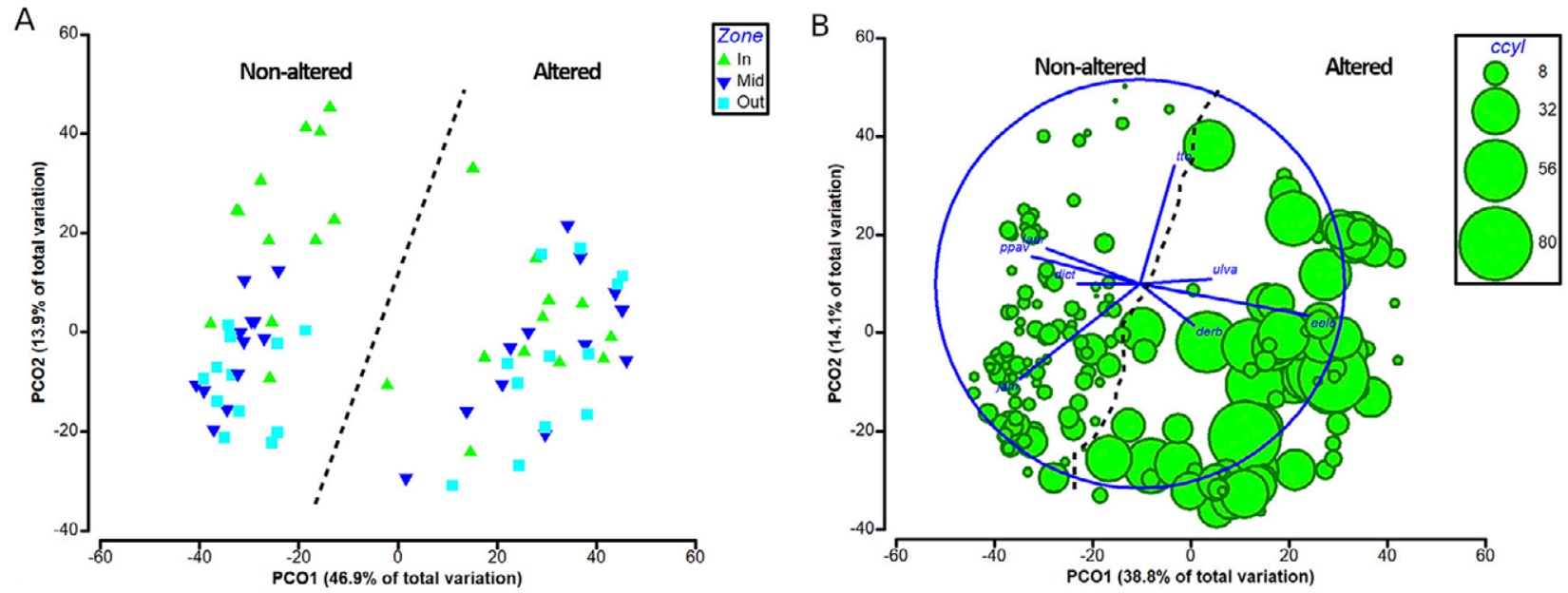

Fig. 4. - Principal coordinates ordination (PCO) of all inventories based on a Bray-Curtis similarity matrix of square-root transformed percent cover values of each taxa. Non-degraded location samples are separated from the degraded ones by a dotted line. A, PCO resulting from pooling replicates and sites by calculating the distance between centroids and showing zone adscription for each inventory. B, PCO without pooling showing the vector overlay of taxa with a correlation higher than 0.3 with the PCO axes. The percentage cover of $C$. cylindracea is also represented through a bubble plot. Taxa legend: eelo, E. elongata; derb, D. tenuissima; dict, Dictyota spp.; jani, Jania spp.; laur, Laurencia complex; ppav, P. pavonica; tto, turf-forming thalli; ulva, U. laetevirens.

phosiphonia spp., Polysiphonia spp.). Among all these taxa, Jania spp., the Laurencia complex, P. pavonica and Dictyota spp. at the non-degraded location and $E$. elongata, Jania spp. and U. laetevirens at the degraded one were the main overstory-formers.

The abundance pattern of overstory during an annual cycle in each zone differed by location and date according to the marginal interaction effect found between these fixed factors $(\mathrm{p}=0.051)$ (Table 2, Fig. 5). There was an increasing trend in overstory cover towards the outer margin (middle and outer zones), and the degraded location showed greater variability over time. This variability was dampened in the outer platform zone, where there was still a sharp drop in June and July 2017. Additionally, the non-degraded location had a higher turnover of overstory species, not only between zones but also over time, whereas in the degraded one that overstory role was mostly carried out by E. elongata, and to a lesser extent by Jania spp. (Figs 5, 6).

\section{Distribution pattern of $C$. cylindracea}

Caulerpa cylindracea abundance was also affected by the interaction between location, zone, and date

Table 2. - A, summary of a four-factor PERMANOVA univariate test (with location, zone, date and site nested in location) comparing overstory cover values from all the samples. Lo, location; $\mathrm{Zo}$, zone; $\mathrm{Da}$, date; $\mathrm{Si}$, site; $\left(^{*}\right)$ Monte Carlo $\mathrm{p}$-value $=0.001$. $\mathrm{B}$, pairwise tests for the term 'LoxZoxDa' for pairs of levels of the factor 'Location' (Monte Carlo p-values).

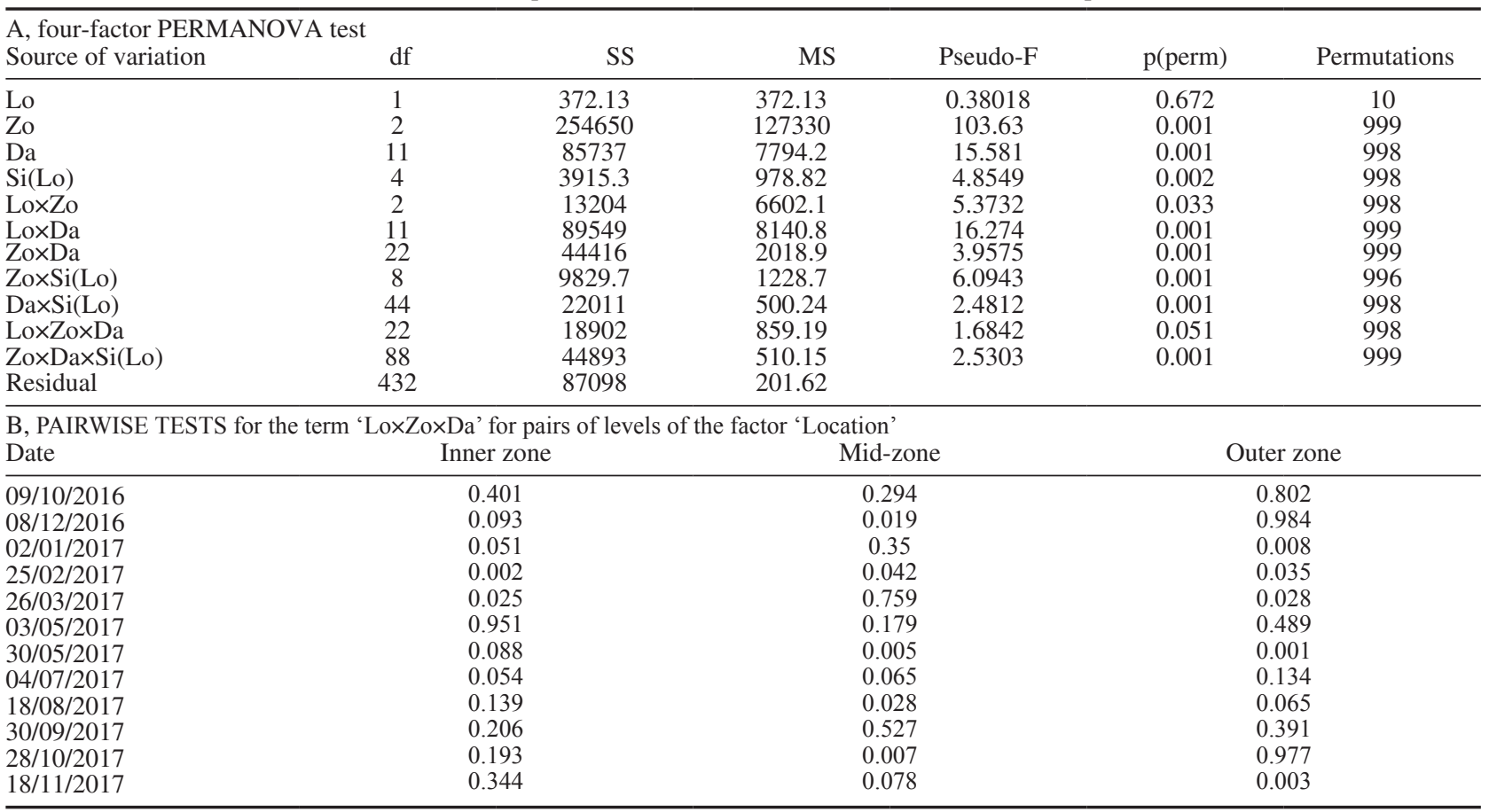



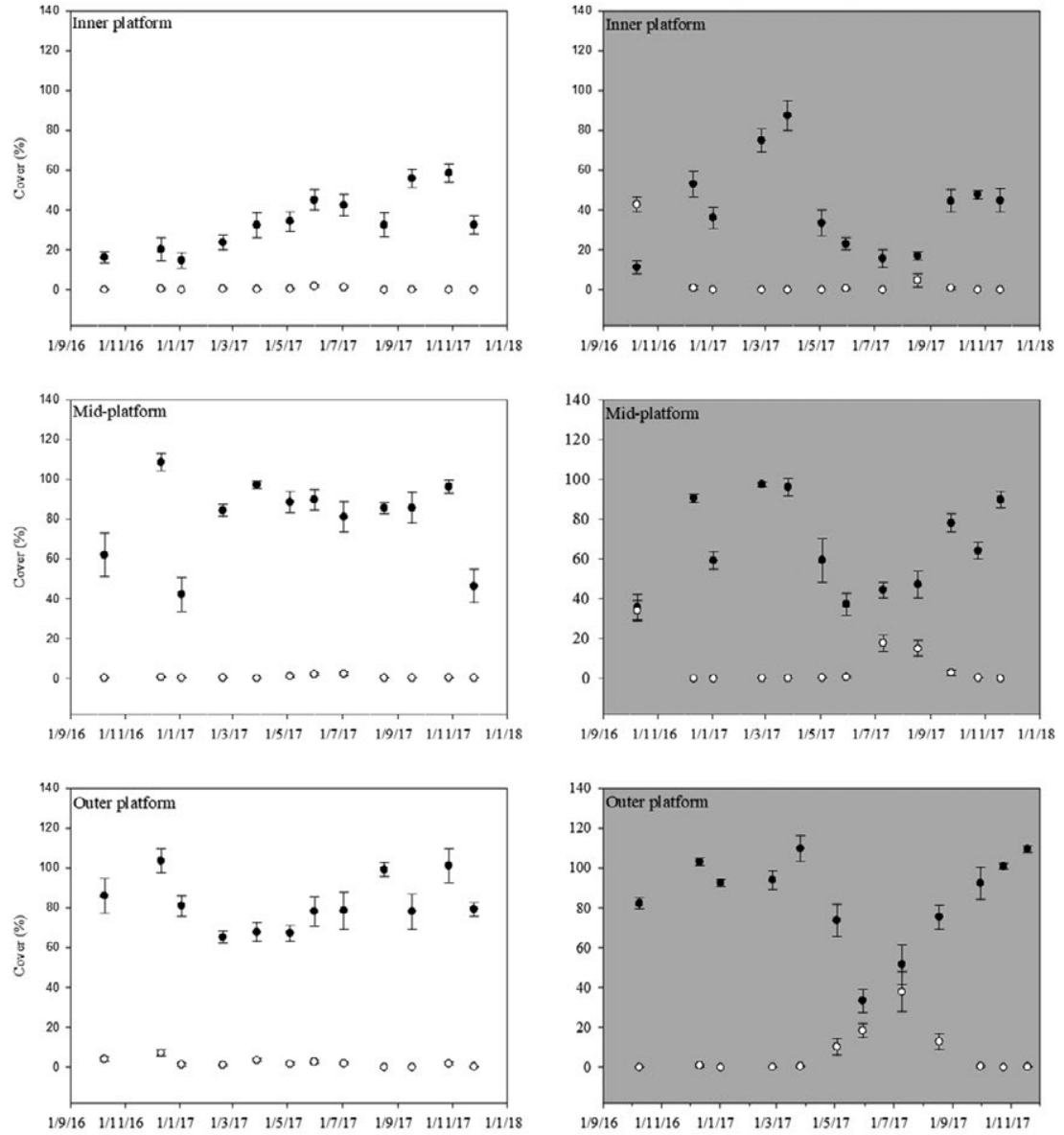
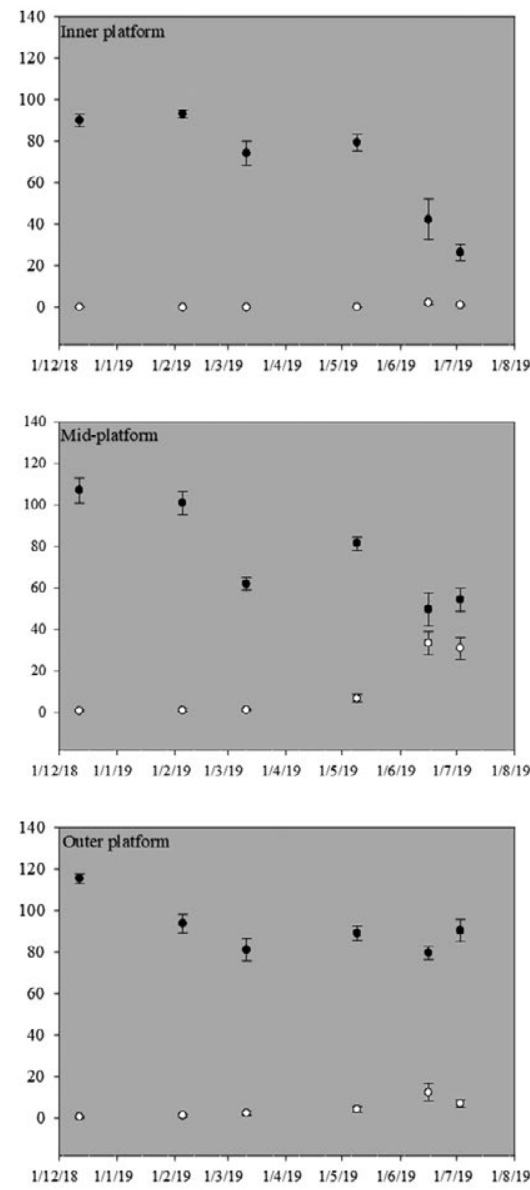

Fig. 5. - Temporal dynamics in the cover of overstory (black dots) and C. cylindracea (white dots) under non-degraded (white background) and degraded (grey background) conditions in the zones distributed along the shallow vermetid platforms. Data from a current survey being carried out at the degraded location (2019) are also shown (right column).

Table 3. - A, summary of a four-factor PERMANOVA univariate test (with location, zone, date and site nested in location) comparing Caulerpa cylindracea cover values from all the samples. Lo, location; Zo, zone; Da, date; Si, site; (*) Monte Carlo p-value=0.001. B, pairwise tests for the term 'LoxZoxDa' for pairs of levels of the factor 'Location' (Monte Carlo p-values).

\begin{tabular}{lccccc}
\hline $\begin{array}{l}\text { A, four-factor PERMANOVA test } \\
\text { Source of variation }\end{array}$ & df & SS & MS & Pseudo-F & p(perm) \\
\hline Lo & 1 & 3468.1 & 3468.1 & 575.93 & 0.107 \\
Zo & 2 & 519.49 & 259.74 & 7.25 & 0.024 \\
Da & 11 & 11400 & 1036.4 & 50.43 & 0.001 \\
Si(Lo) & 4 & 24.086 & 6.0216 & 0.196 & 0.944 \\
LoxZo & 2 & 64.623 & 32.312 & 0.90 & 0.409 \\
LoxDa & 11 & 10324 & 938.59 & 45.671 & 0.001 \\
ZoxDa & 22 & 8436.9 & 383.49 & 10.763 & 0.001 \\
ZoxSi(Lo) & 8 & 286.71 & 35.839 & 1.1702 & 0.312 \\
DaxSi(Lo) & 44 & 904.24 & 20.551 & 0.67 & 0.961 \\
LoxZoxDa & 22 & 10177 & 462.6 & 12.98 & 990 \\
ZoxDaxSi(Lo) & 88 & 31354 & 35.63 & 1.16 & 990 \\
Res & 432 & 13231 & 30.627 & 998 & 0.159 \\
\end{tabular}

B, PAIRWISE TESTS for the term 'LoxZo×Da' for pairs of levels of the factor 'Location'

\begin{tabular}{lccc} 
Date & Inner zone & Mid-zone & Outer zone \\
\hline $09 / 10 / 2016$ & 0.003 & 0.002 & 0.064 \\
$08 / 12 / 2016$ & 0.661 & 0.067 & 0.029 \\
$02 / 01 / 2017$ & - & 0.082 & 0.155 \\
$25 / 02 / 2017$ & 0.372 & 0.56 & 0.062 \\
$26 / 03 / 2017$ & 0.266 & - & 0.009 \\
$03 / / 55 / 2017$ & 0.357 & 0.3 & 0.2 \\
$30 / / 5 / 2017$ & 0.203 & 0.089 & 0.004 \\
$04 / / 7 / 2017$ & 0.012 & 0.047 & 0.004 \\
$18 / / 88 / 2017$ & 0.154 & 0.259 & 0.406 \\
$30 / 09 / 2017$ & 0.433 & - & 0.034 \\
$28 / 10 / 2017$ & - & 0.389 & 0.696 \\
$18 / 11 / 2017$ & - & &
\end{tabular}


Cabo Huertas
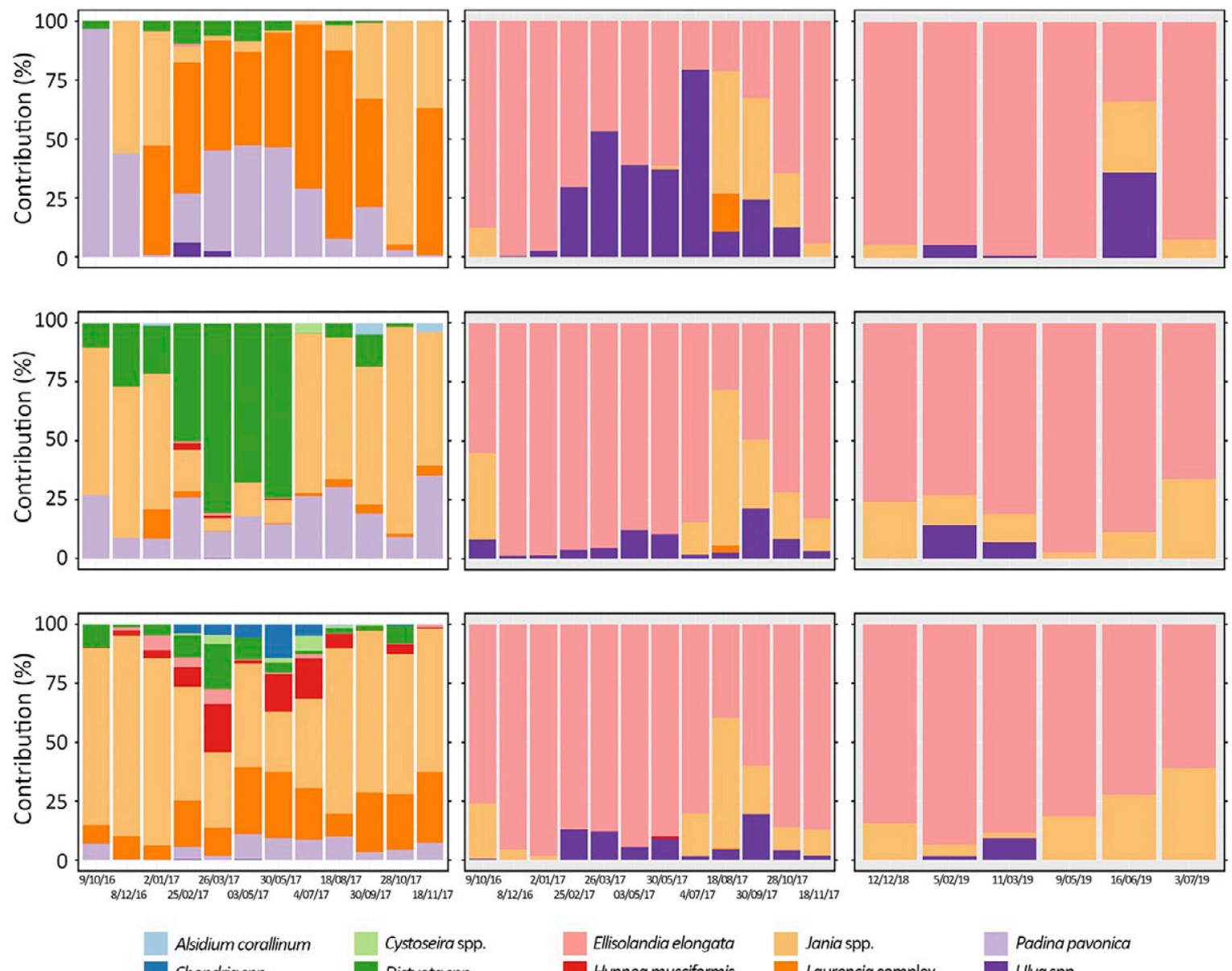

Mid

platform
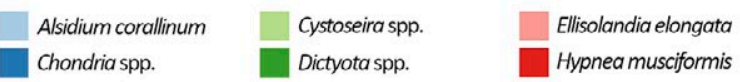

Jania spp.
Laurencia complex

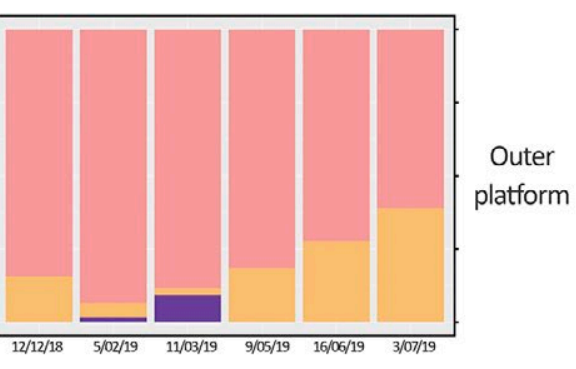

Fig. 6. - Stacked plots showing the proportion of each algae contributing to the total overstory cover in each survey. The graphics are arranged as in Figure 5.

(Table 3A). It usually showed higher cover values in the degraded location and the outer platform zone, but cover values showed a temporal variability (Fig. 4B, Table 3B). At the non-degraded location, the cover values were low during an entire annual cycle, whereas at the degraded one there was a peak during June and July 2017 in the middle and outer platform zones, and another peak in October 2016 in the inner and middle platform zones (Fig. 5). These peaks always coincided with the low cover values of the overstory. The same pattern is shown in a current survey being carried out at the same degraded location. In this case, the July peak is not observed in the outermost zone, where overstory values remained high (Fig. 5).

\section{DISCUSSION}

In this study, the main differences in the composition of assemblages between locations are even greater than those within them along the entire platform width. Local drivers acting at the degraded location could explain the sharp differences found between locations. However, the specific causes driving a community shift in urban areas are still an open issue (Benedetti-Cecchi et al. 2001, Bertocci et al. 2017, Mancuso et al. 2018) and are far beyond the scope of this study. Even so, the correlation between urbanization and the replacement of fucoid algae and other phaeophycean groups by E. elongata is well known in the Mediterranean Sea (Pinedo et al. 2007, Mangialajo et al. 2008, Pinedo and Ballesteros 2019), pointing to eutrophication and sedimentation among the most essential drivers of change in anthropogenic-affected habitats (Munda 1993, Airoldi 2003, Pinedo et al. 2015). Moreover, these factors could interact synergistically, favouring the growth of turf algae that hampers the recruitment of other algal species (Gorgula and Connell 2004).

Being correlative, the results of this study do not reveal any cause-effect relationship between the low ecological status of the degraded location and its values in nutrient concentration and sediment cover. Furthermore, the high variability found leads to difficulties in interpreting the role of these variables at both locations, though at the degraded location there is a slight trend towards higher values of sediment cover and nutrient concentration.

The higher algal cover values found in the outer zones of each location could easily be related to the fact that their productivity potential (Steneck and Dethier 1994) is higher than that of the inner ones (Ter- 
radas-Fernández et al. 2018) and to the lower effect of low sea level events (pers. obs.). There is a clear homogenization of assemblages at the degraded location, where E. elongata determines its annual dynamics. The decline episodes in these articulated algae could be related to natural stressors such as low sea level events, high light intensity and high temperatures, all of which could act together, intensifying this decline. These episodes have also been reported, especially during summer months, in other very shallow systems dominated by articulated corallines (Benedetti-Cecchi and Cinelli 1994, Guerra-García et al. 2011, Bertocci et al. 2012). On the other hand, at the non-degraded location, the greater diversity in species and their temporal replacement keep a high overstory cover in the outer margin zones throughout the year.

The lack of replacement of articulated corallines by other overstory species could act as a key point in determining the abundance of $C$. cylindracea at the degraded location. Thus, the low ecological status of the overstory could act as potential driver of the invasion (Piazzi et al. 2016 and references therein). This spread of $C$. cylindracea could be fostered in warmer months, when the decline of E. elongata coincides with the optimal growth temperature for $C$. cylindracea (Samperio-Ramos et al. 2015). Then, presumably, C. cylindracea could take advantage of both the free space generated by E. elongata decay and the "thermal opportunity window". However, some competitive interaction between E. elongata and $C$. cylindracea cannot be ruled out. The lack of detection of $C$. $c y$ lindracea populations beyond the studied platforms suggests that the growth of $C$. cylindracea is due to a persistent resting stage rather than to propagule-recruitment processes (Uyà et al. 2017), taking into account the unlikely sexual reproduction for C. cylindracea (Varela-Álvarez et al. 2012).

The higher stress occurring in the inner zones may hamper the invasiveness of $C$. cylindracea towards the inner parts of the platform. However, the high cover of C. cylindracea observed in the inner degraded zone in October 2016, coinciding with the low overstory cover, could be the result of high sea level episodes improving the growth of $C$. cylindracea. This scenario is likely to occur in late summer and autumn months, when the mean sea level is usually higher in the souteastern Iberian Peninsula (Soto 1987, Adloff et al. 2018).

All in all, in this study our results indicate that $C$. cylindracea acts rather like an opportunistic species, taking advantage of the less persistent overstory at the affected location. Though competitive interactions cannot be ruled out, factors affecting the recipient degraded overstory seem to better explain the decay of this overstory than interactive processes with $C$. cylindracea. This decline, when abiotic conditions are optimal for $C$. cylindracea growth, would be harnessed by this alien species, in line with Bulleri et al. (2010). Thus, $C$. cylindracea would rather behave as a passenger of change on these degraded platforms (MacDougall and Turkington 2005). However, stressors such as sedimentation and eutrophication could also foster $C$. cylindracea establishment (Piazzi et al. 2005, Gennaro and Piazzi 2011), and once established, C. cylindracea could enhance sediment accumulation, acting as a driver (Bulleri et al. 2010). Thus, the slightly higher values of both stressors at the degraded location makes their role as enhancers of $C$. cylindracea growth feasible. Owing to the high level of homogenization of the assemblages from the degraded and urbanized Mediterranean littoral fringe, the establishment and enhancement of $C$. cylindracea growth on other degraded Mediterranean vermetid platforms is plausible.

Further studies, especially long-term manipulative and correlative ones, are required to understand better how the ecological status of vermetid platforms affects the invasiveness of $C$. cylindracea. Possible future scenarios linked to global change are of particular concern: among others, the higher extremeness trend of disturbances such as storms and low sea level episodes, which could affect the overstory cover of the vermetid platforms (Sanz-Lázaro 2016, Zamir et al. 2018).

\section{ACKNOWLEDGEMENTS}

This work was partially funded by the project GRE14-19 of the University of Alicante. We are thankful to Alberto Baraza, Aitor Navarro, Ana Belen Jodar, Lotte Krüger, Luís Enrique Alcaraz, Carlos Botana and Leticia Asensio for their help in the fieldwork. We are also thankful to J. Zubcoff for statistical advice. Ivan Egea helped us to improve the English grammar and two anonymous reviewers contributed to the improvement of the manuscript. C. S. was supported as "Investigador Distinguido" by the University of Alicante (Ref. UATALENTO 17-11).

This work is part of the PhD thesis of Marc Terradas Fernandez.

\section{REFERENCES}

Adloff F., Jordà G., Somot S., et al. 2018. Improving sea level simulation in Mediterranean regional climate models. Clim. Dyn. 51: $1167-1178$.

https://doi.org/10.1007/s00382-017-3842-3

Aguilar J. 2009. Seguimiento de la comunidad fitoplanctónica influenciada por actividades antrópicas en la bahía de Alicante (SE de la península Ibérica). MSc. thesis, Univ. Alicante.

Airoldi L. 2003. The effects of sedimentation on rocky coast assemblages. Oceanogr. Mar. Biol. Annu. Rev. 41: 161-236.

Airoldi L., Turon X., Perkol-Finkel S., et al. 2015. Corridors for aliens but not for natives: effects of marine urban sprawl at a regional scale. Divers. Distrib. 21: 755-768. https://doi.org/10.1111/ddi.12301

Altamirano M., Andreakis N., Souza-Egipsy V., et al. 2014. First record of Caulerpa cylindracea (Caulerpaceae, Chlorophyta) in Andalusia (Southern Spain). An. Jar. Bot. Mad. 71: e007. https://doi.org/10.3989/ajbm.2381

Anderson M.J., Gorley R.N., Clarke K.R. 2008. PERMANOVA+ for PRIMER: Guide to Software and Statistical Methods. PRIMER-E, Plymouth, 244 pp.

Aranda A., Gras D., Guillén J.E., et al. 1994. Estudio bionómico de la Bahía de Alicante. Inst. Ecol. Lit, Ayuntamiento de Alicante, $172 \mathrm{pp}$.

Badreddine A., Milazzo M., Saab M.A.A., et al. 2019. Threatened biogenic formations of the Mediterranean: Current status and assessment of the vermetid reefs along the Lebanese coastline (Levant basin). Ocean Coast Manage.169: 137-146. https://doi.org/10.1016/j.ocecoaman.2018.12.019

Balistreri P., Mannino A.M. 2017. Preliminary data on the occurrence of alien macroalgae in the vermetid reef along the coasts of Favignana Island (Southern Tyrrhenian Sea). Biodiversity J. 
8: $105-112$.

Ballesteros E., Torras X., Pinedo S., et al. 2007. A new methodology based on littoral community cartography dominated by macroalgae for the implementation of the European Water Framework Directive. Mar. Poll. Bull. 55: 172-180. https://doi.org/10.1016/j.marpolbul.2006.08.038

Benedetti-Cecchi L., Cinelli F. 1994. Recovery of patches in an assemblage of geniculate coralline algae: variability at different successional stages. Mar. Ecol. Prog. Ser. 110: 9-18. https://doi.org/10.3354/meps110009

Benedetti-Cecchi L., Pannacciulli F., Bulleri F., et al. 2001. Predicting the consequences of anthropogenic disturbance: large-scale effects of loss of canopy algae on rocky shores. Mar. Ecol. Prog. Ser. 214: 137-150. https://doi.org/10.3354/meps214137

Bertocci I., Araújo R., Incera M., et al. 2012. Benthic assemblages of rock pools in northern Portugal: seasonal and between-pool variability. Sci. Mar. 76: 781-789. https://doi.org/10.3989/scimar.03669.21A

Bertocci I., Domínguez Godino J.A., Freitas C., et al. 2017. Compounded perturbations in coastal areas: contrasting responses to nutrient enrichment and the regime of storm-related disturbance depend on life-history traits. Funct. Ecol. 31: 1122-1134. https://doi.org/10.1111/1365-2435.12815

Boudouresque C.F., Meinesz A., Ribera M.A., et al. 1995. Spread of the green alga Caulerpa taxifolia (Caulerpales, Chlorophyta) in the Mediterranean: possible consequences of a major ecological event. Sci. Mar. 59: 21-29.

Boudouresque C.F., Verlaque M. 2002. Biological pollution in the Mediterranean Sea: invasive versus introduced macrophytes. Mar. Poll. Bull. 44: 32-38. https://doi.org/10.1016/S0025-326X(01)00150-3

Bulleri F., Balata D., Bertocci I., et al. 2010. The seaweed Caulerpa racemosa on Mediterranean rocky reefs: from passenger to driver of ecological change. Ecology 91: 2205-2212. https://doi.org/10.1890/09-1857.

Bulleri F., Benedetti-Cecchi L., Ceccherelli G., et al. 2017. A few is enough: a low cover of a non-native seaweed reduces the resilience of Mediterranean macroalgal stands to disturbances of varying extent. Biol. Invasions 19: 2291-2305. https://doi.org/10.1007/s10530-017-1442-0

Cantasano N., Pellicone G., Di Martino V. 2017. The spread of Caulerpa cylindracea in Calabria (Italy) and the effects of shipping activities. Ocean Coast Manag. 144 : 51-58. https://doi.org/10.1016/j.ocecoaman.2017.04.014

Ceccherelli G., Piazzi L., Balata D. 2002. Spread of introduced Caulerpa species in macroalgal habitats. J. Exp. Mar. Biol. Ecol. 280: 1-11. https://doi.org/10.1016/S0022-0981(02)00336-2

Ceccherelli G., Pinna S., Cusseddu V., et al. 2014. The role of disturbance in promoting the spread of the invasive seaweed Caulerpa racemosa in seagrass meadows. Biol. Invasions 16: 2737-2745

https://doi.org/10.1007/s10530-014-0700-7

Cheminée A., Merigot B., Vanderklift M.A., et al. 2016. Does habitat complexity influence fish recruitment? Mediterr. Mar. Sci. 17: $39-46$. https://doi.org/10.12681/mms.1231

Clarke K., Gorley R. 2015. PRIMER v7: User Manual/Tutorial. PRIMER-E, Plymouth, 296 pp.

Connell S.D., Russell B.C., Turner D.J., et al. 2008. Recovering a lost baseline: missing kelp forests on a metropolitan coast. Mar. Ecol. Prog. Ser. 360: 63-72. https://doi.org/10.3354/meps07526

Dethier M.N., Graham E.S., Cohen S., et al. 1993. Visual versus random-point percent cover estimations: 'objective' is not always better. Mar. Ecol. Prog. Ser. 96: 93-100. https://doi.org/10.3354/meps096093

Didham R.K., Tylianakis J.M., Gemmell N.J., et al. 2007. Interactive effects of habitat modification and species invasion on native species decline. Trends Ecol. Evol. 22: 489-496. https://doi.org/10.1016/j.tree.2007.07.001

Enguix A.M., Argente J., Chicharro J., et al. 2014. Estacionalidad y colonización de Caulerpa racemosa var. cylindracea en espacios naturales protegidos marinos de la Comunidad Valenciana. Chron. Nat. 4: 21-33.

Galil B.S. 2013. Going going gone: the loss of a reef building gastropod (Mollusca: Caenogastropoda: Vermetidae) in the southeast Mediterranean Sea. Zool. Middle East 59: 179-182. https://doi.org/10.1080/09397140.2013.810885
García M., Weitzmann B., Pinedo S., et al. 2015. First report on the distribution and impact of marine alien species in Coastal Benthic assemblages along the Catalan Coast. In: Munné A., Ginebreda A., Prat N. (eds), Experiences from Ground, Coastal and Transitional Water Quality Monitoring. Springer, pp. 249-270. https://doi.org/10.1007/698_2015_411

Gennaro P., Piazzi L. 2011. Synergism between two anthropic impacts: Caulerpa racemosa var. cylindracea invasion and seawater nutrient enrichment. Mar. Ecol. Prog. Ser. 427: 59-70. https://doi.org/10.3354/meps09053

Gorgula S.K., Connell S.D. 2004. Expansive covers of turf-forming algae on human-dominated coast: the relative effects of increasing nutrient and sediment loads. Mar. Biol. 145: 613-619. https://doi.org/10.1007/s00227-004-1335-5

Guerra-García J.M., Cabezas M.P., Baeza-Rojano E., et al. 2011. Spatial patterns and seasonal fluctuations of intertidal macroalgal assemblages from Tarifa Island, southern Spain: relationship with associated Crustacea. J. Mar. Biol. Assoc. U.K. 91: 107-116.

https://doi.org/10.1017/S0025315410001219

Huenneke L.F., Hamburg S.P., Koide R., et al. 1990. Effects of soil resources on plant invasion and community structure in Californian serpentine grassland. Ecology 71: 478-491. https://doi.org/10.2307/1940302

Katsanevakis S., Wallentinus I., Zenetos A., et al. 2014. Impacts of invasive alien marine species on ecosystem services and biodiversity: a pan-European review. Aquat. Invasions 9: 391-423. https://doi.org/10.3391/ai.2014.9.4.01

Klein J., Verlaque M. 2008. The Caulerpa racemosa invasion: a critical review. Mar. Pollut. Bull. 56: 205-225. https://doi.org/10.1016/j.marpolbul.2007.09.043

Laborel J., Kempf M. 1965. Formações de vermetos e algas calcárias nas costas do Brasil. Trabal. Inst. Ocean. UFPE 7/8: 33-50. https://doi.org/10.5914/tropocean.v7i1.2500

MacDougall A.S., Turkington R. 2005. Are invasive species the drivers or passengers of change in degraded ecosystems? Ecology $86: 42-55$. https://doi.org/10.1890/04-0669

Mancuso F.P., Strain E.M.A., Piccioni E., et al. 2018. Status of vulnerable Cystoseira populations along the Italian infralittoral fringe, and relationships with environmental and anthropogenic variables. Mar. Poll. Bull. 129: 762-771. https://doi.org/10.1016/j.marpolbul.2017.10.068

Mangialajo L., Chiantore M., Cattaneo-Vietti R. 2008. Loss of fucoid algae along a gradient of urbanisation, and structure of benthic assemblages. Mar. Ecol. Prog. Ser. 358: 63-74. https://doi.org/10.3354/meps07400

Marín-Guirao L., Bernardeau-Esteller J., Ruiz J.M., et al. 2015. Resistance of Posidonia oceanica seagrass meadows to the spread of the introduced green alga Caulerpa cylindracea: assessment of the role of light. Biol. Invasions 17: 1989-2009. https://doi.org/10.1007/s10530-015-0852-0

Milazzo M., Badalamenti F., Riggio S., et al. 2004. Patterns of algal recovery and small-scale effects of canopy removal as a result of human trampling on a Mediterranean rocky shallow community. Biol. Conserv. 117: 191-202. https://doi.org/10.1016/S0006-3207(03)00292-1

Milazzo M., Rodolfo-Metalpa R., San Chan V.B., et al. 2014. Ocean acidification impairs vermetid reef recruitment. Sci. Rep. 4: 4189. https://doi.org/10.1038/srep04189

Milazzo M., Fine M., La Marca E.C., et al. 2016. Drawing the Line at Neglected Marine Ecosystems: Ecology of Vermetid Reefs in a Changing Ocean. In: Rossi S., Bramanti L., Gori A., et al. (eds), Marine Animal Forests. Springer International Publishing AG, Switzerland, pp. 345-367. https://doi.org/10.1007/978-3-319-17001-5

Montefalcone M., Morri C., Parravicini V., et al. 2015. A tale of two invaders: divergent spreading kinetics of the alien green algae Caulerpa taxifolia and Caulerpa cylindracea. Biol. Invasions 17: 2717-2728 https://doi.org/10.1007/s10530-015-0908-1

Munda I.M. 1993. Changes and degradation of seaweed stands in the Northern Adriatic. Hydrobiologia 260/261: 239-253. https://doi.org/10.1007/BF00049025

Pena-Martín C., Fernanz J.C.C., Crespo M.B., et al. 2003. Caulerpa racemosa (Forssk.) J. Agardh (Caulerpaceae, Chlorophyceae), nueva para la flora de Alicante. Anales Jard. Bot. Madrid 60: 448-449.

Piazzi L., Balata D., Ceccherelli G., et al. 2005. Interactive effect 
of sedimentation and Caulerpa racemosa var. cylindracea invasion on macroalgal assemblages in the Mediterranean Sea. Estuar. Coast. Shelf Sci. 64: 467-474 https://doi.org/10.1016/j.ecss.2005.03.010

Piazzi L., Balata D., Bulleri F., et al. 2016. The invasion of Caulerpa cylindracea in the Mediterranean: the known, the unknown and the knowable. Mar. Biol. 163: 161. https://doi.org/10.1007/s00227-016-2937-4

Pinedo S., Ballesteros E. 2019. The role of competitor, stress-tolerant and opportunist species in the development of indexes based on rocky shore assemblages for the assessment of ecological status. Ecol. Indic. 107: 105556 https://doi.org/10.1016/j.ecolind.2019.105556

Pinedo S., García M., Satta M.P., et al. 2007. Rocky-shore communities as indicators of water quality: a case study in the Northwestern Mediterranean. Mar. Poll. Bull. 55: 126-135. https://doi.org/10.1016/j.marpolbul.2006.08.044

Pinedo S., Arévalo R., Ballesteros E. 2015. Seasonal dynamics of upper sublittoral assemblages on Mediterranean rocky shores along a eutrophication gradient. Est. Coast. Shelf Sci. 161: 93-101. https://doi.org/10.1016/j.ecss.2015.05.004

Ponti M., Turicchia E., Ferro F., et al. 2018. The understorey of gorgonian forests in mesophotic temperate reefs. Aquat. Conserv. 28: 1153-1166. https://doi.org/10.1002/aqc.2928

Ramos-Esplà A., Vázquez M., Izquierdo A. 2008. Cartografía de las formaciones de vermétidos en la Comunidad Valenciana y evaluación de su estado de conservación. D.G. Biodiversidad-Generalitat Valenciana, CIMAR-Universidad de Alicante, 120 pp.

Ramos-Esplà A, Vázquez M, Izquierdo A, et al. 2011. Estudio del estado de conservación de las comunidades bentónicas de substrato duro en la franja litoral de la Comunidad Valenciana, en aplicación de la Directiva Marco del Agua. D.G. BiodiversidadGeneralitat Valenciana, CIMAR-Universidad de Alicante, $91 \mathrm{pp}$.

Rilov G., Benayahu Y., Gasith A. 2004. Prolonged lag in population outbreak of an invasive mussel: a shifting-habitat model. Biol. Invasions 6: 347-364. https://doi.org/10.1023/B:BINV.0000034614.07427.96

Rilov G., Galil B. 2009. Marine Bioinvasions in the Mediterranean Sea - History, Distribution and Ecology. In: Rilov G., Crooks J.A. (eds), Biological invasions in marine ecosystems. Springer, Berlin, pp. 549-575. https://doi.org/10.1007/978-3-540-79236-9_31

Ruitton S., Javel F., Culioli J.M., et al. 2005. First assessment of the Caulerpa racemosa (Caulerpales, Chlorophyta) invasion along the French Mediterranean coast. Mar. Poll. Bull. 50:1061-1068. https://doi.org/10.1016/j.marpolbul.2005.04.009

Ruiz J.M., Marín-Guirao L., Bernardeau-Esteller J., et al. 2011. Spread of the invasive alga Caulerpa racemosa var. cylindracea (Caulerpales, Chlorophyta) along the Mediterranean Coast of the Murcia region (SE Spain). Anim. Biodivers. Conserv. 34: 73-82.

Safriel U.N. 1975. The role of vermetid gastropods in the formation of Mediterranean and Atlantic reefs. Oecologia 20: 85-101. https://doi.org/10.1007/BF00364323

Samperio-Ramos G., Olsen Y.S., Tomas F., et al. 2015. Ecophysiological responses of three Mediterranean invasive seaweeds (Acrothamnion preissii, Lophocladia lallemandii and Caulerpa cylindracea) to experimental warming. Mar. Poll. Bull. 96: 418-423.

https://doi.org/10.1016/j.marpolbul.2015.05.024

Sanz-Lázaro C. 2016. Climate extremes can drive biological assemblages to early successional stages compared to several mild disturbances. Sci. Rep. 6: 30607. https://doi.org/10.1038/srep30607

Soto J. 1987. Estudio florístico, corológico, autoecológico y sinecológico de las algas bentónicas marinas del Sureste de la Península Ibérica. PhD thesis, Univ. Málaga, 507 pp.

Steneck R.S., Dethier M.N. 1994. A functional group approach to the structure of algal-dominated communities. Oikos. 69: 476-498. https://doi.org/10.2307/3545860

Templado J., Richter A., Calvo M. 2016. Reef building Mediterranean vermetid gastropods: disentangling the Dendropoma petraeum species complex. Mediterr. Mar. Sci. 17: 13-31. https://doi.org/10.12681/mms.1333

Terradas-Fernández M., Botana-Gómez C., Valverde-Urrea M., et al. 2018. The dynamics of phytobenthos and its main drivers on abrasion platforms with vermetids (Alicante, Southeastern Iberian Peninsula). Mediterr. Mar. Sci. 19: 58-68. https://doi.org/10.12681/mms.14143

Uyà M., Maggi E., Mori G., et al. 2017. Carry over effects of nutrient addition on the recovery of an invasive seaweed from the winter die-back. Mar. Environ. Res. 126: 37-44. https://doi.org/10.1016/j.marenvres.2017.02.006

Varela-Alvarez E., Garreta A.G., Lluch J.R., et al. 2012. Mediterranean species of Caulerpa are polyploid with smaller genomes in the invasive ones. PLoS ONE 7: e47728. https://doi.org/10.1371/journal.pone.0047728

Verlaque M., Durand C., Huisman J.M., et al. 2003. On the identity and origin of the Mediterranean invasive Caulerpa racemosa (Caulerpales, Chlorophyta). Eur. J. Phycol. 38: 325-339. https://doi.org/10.1080/09670260310001612592

Zamir R., Alpert P., Rilov G. 2018. Increase in Weather Patterns Generating Extreme Desiccation Events: Implications for Mediterranean Rocky Shore Ecosystems. Est. Coasts 41: 1868-1884. https://doi.org/10.1007/s12237-018-0408-5

\section{SUPPLEMENTARY MATERIAL}

The following supplementary material is available through the online version of this article and at the following link:

http://scimar.icm.csic.es/scimar/supplm/sm04984esm.pdf

Table S1. - A, summary of a two-factor PERMANOVA univariate test (with location and date) comparing nutrient concentration (phosphates and nitrogen including ammonia, nitrates and nitrites) between samples. Lo, location; Da, date. B, pairwise tests for the term 'LoxDa' for pairs of levels of the factor 'Location' (Monte Carlo p-values)

Table S2. - A, summary of a four-factor PERMANOVA univariate test (with location, zone, date and site nested in location) comparing sediment cover between samples. Lo, location; Da, date. $\mathrm{B}$, pairwise tests for the term 'Lo $\times$ Zo $\times$ Da' for pairs of levels of the factor 'Location' (Monte Carlo p-values). 


\section{Bathyal cumacean assemblages from the southern margin of the Cap Ferret Canyon (SE Bay of Biscay)}

Jordi Corbera, Jean Claude Sorbe

Supplementary material 
S2 • J. Corbera and J.C. Sorbe

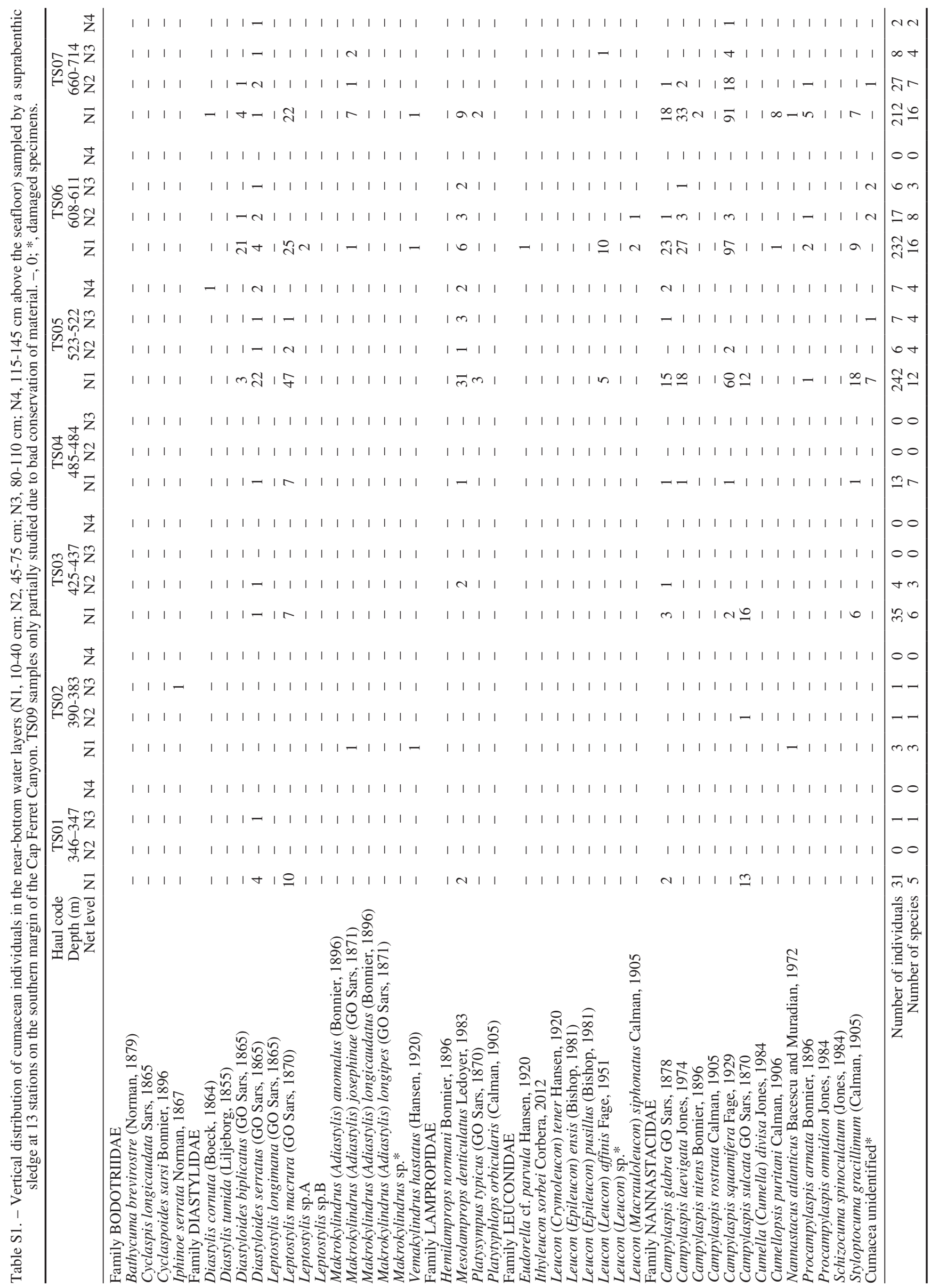




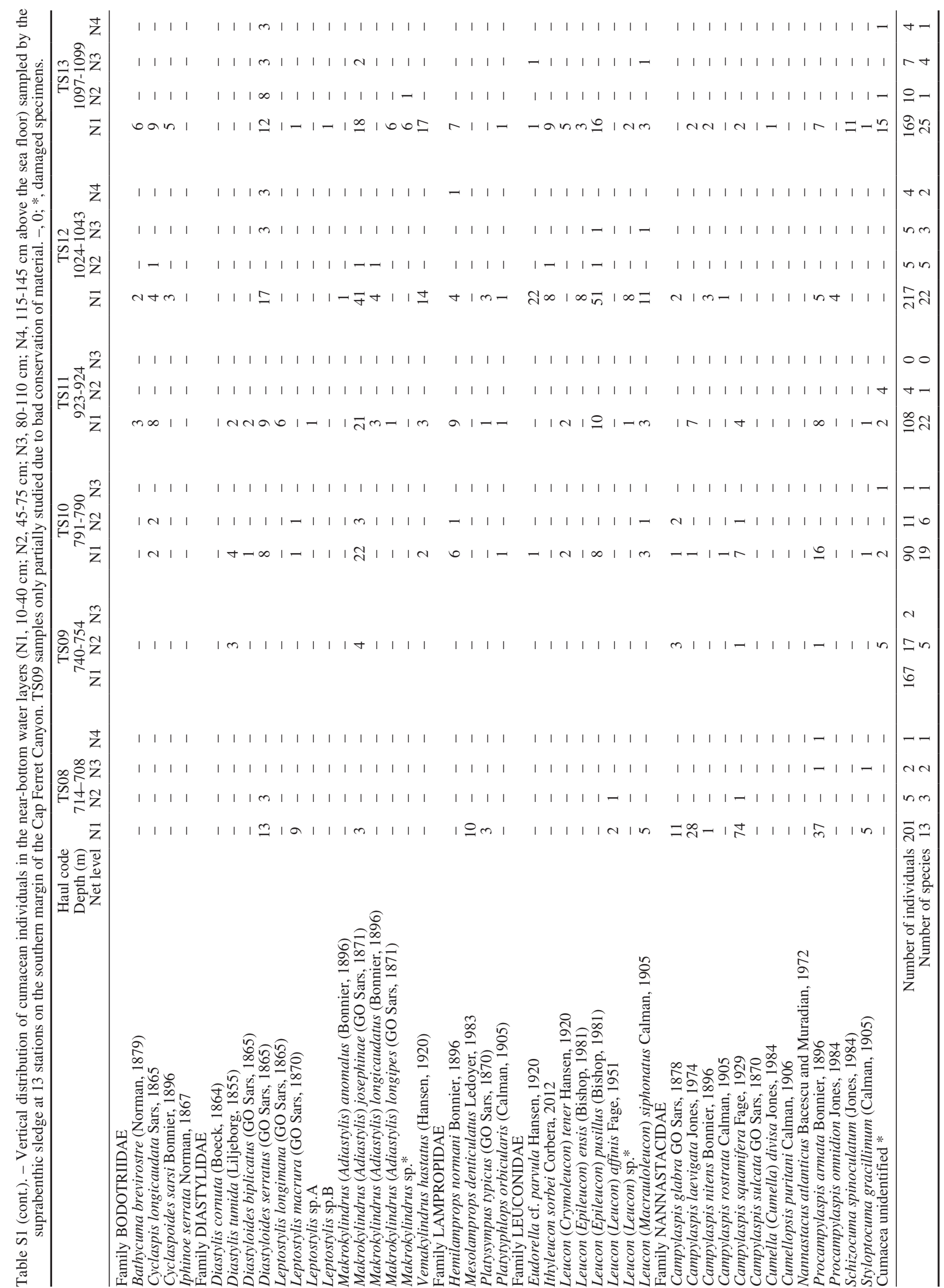

